\title{
ANALYSIS OF COMPETITIVENESS IN THE NBA REGULAR
} SEASONS

\author{
Yves de Saá Guerra, Juan Manuel Martín González, Nieves Arjonilla López, \\ Samuel Sarmiento Montesdeoca, David Rodríguez Ruiz, Juan Manuel García Manso \\ University of Las Palmas de Gran Canaria, Canary Island, Spain
}

\begin{abstract}
Research background and hypothesis. Several attempts have been made to understand some modalities of sport from the point of view of complexity. Most of these studies deal with this phenomenon with regard to the mechanics of the game itself (in isolation). Nevertheless, some research has been conducted from the perspective of competition between teams. Our hypothesis was that for the study of competitiveness levels in the system of league competition our analysis model (Shannon entropy), is a useful and highly sensitive tool to determine the degree of global competitiveness of a league.

Research aim. The aim of our study was to develop a model for the analysis of competitiveness level in team sport competitions based on the uncertainty level that might exist for each confrontation.

Research methods. Degree of uncertainty or randomness of the competition was analyzed as a factor of competitiveness. It was calculated on the basis of the Shannon entropy.

Research results. We studied 17 NBA regular seasons, which showed a fairly steady entropic tendency. There were seasons less competitive $(\leq 0.9800)$ than the overall average $(0.9835)$, and periods where the competitiveness remained at higher levels (range: 0.9851 to 0.9902 ).

Discussion and conclusions. A league is more competitive when it is more random. Thus, it is harder to predict the final outcome. However, when the competition is less random, the degree of competitiveness will decrease significantly. The NBA is a very competitive league, there is a high degree of uncertainty of knowing the final result.
\end{abstract}

Keywords: complex systems, basketball, entropy, competition, randomness.

\section{INTRODUCTION}

$\mathrm{T}$ The degree of equality of the playing strengths of teams, competitive degree or competitive balance, is a central concept in the analysis of professional sports leagues. There is considerable interest in tracking movements in competitive balance over time and analysing the effects of regulatory, institutional and other changes, as indicated by the extensive literature on the subject in several sports (Schmidt, Berri, 2001; Fort, Maxcy, 2003; Rhoads, 2004; Goossens, 2006).

Most studies deal with this phenomenon with regard to the mechanics of the game itself (Chatterjee, Yilmaz 1999; McGarry et al., 2002; Lebed 2006; McGarry, Franks, 2007; Passos et al., 2008, Passos et al., 2009), nevertheless, few 
studies do that from the perspective of competition between teams in differents sport (Malacarne, Mendes, 2000; Yilmaz, Chatterjee, 2000; Onody, de Castro, 2004; Mendes et al., 2007; Vaz de Melo et al., 2008; Ribeiro et al., 2010).

The aim of our study was to assess the degree of competitiveness on the basis of the uncertainty level that might exist for each confrontation. We calculated the value of the Shannon entropy which quantifies the information contained by a variable (Shannon, 1948; Robert, 1965; Yeung, 2008), to determine the degree of uncertainty or randomness of the competition.

We can understand the team as a complex systemic unit and the competition - as the emerging enviroment (Gréhaigne et al., 1989), a direct reflection of the nature of the teams and their critical interactions. Herein lies the importance of knowing the behavior of the environment, its relationship and impact on a team as a complex system. The performance of a team is the result of synchronous interaction of certain optimization of its component systems, they are also a reciprocal relationship with the competition, the emerging and critical environment.

The competitive model (type of confrontation) has a direct impact on competition, development and evaluation. Such small changes can alter the outcome, given the close relationship between the competitive model and competition (Lebed, 2006).

Given the difficulty of predicting results of the games, and therefore, the final qualification, we must not use linear methodology for analysis. It is necessary to use a methodology that allows us to explore the nature of the competition with as much detail as possible, as is the theory of complexity.

In complex systems, the processes which occur simultaneously at different scales or levels are important, and the intricate and complex behavior of the system as a whole depends on its units.

Figure 1. Example of a matrix $\mathbf{N}=\mathbf{4}$

Note. The rows represent the games played by a team at home. The columns represent the won or lost games played by a team away. HW (Home Won games) represents the total number of games won by the teams at home. AL (Away Lost) is the lost games away. AW represents the total number of games won away. The final score $\mathrm{R}$ is the sum of the home and away victories, $\mathrm{R}=\mathrm{HW}+\mathrm{AW}, \mathrm{AW}=$ $(\mathrm{N}-1)-\mathrm{AL}$
Although not directly, the structures of complex systems are powerfully related, and often nonlinearly (Goodwin, 2000; Vicsek, 2002; Solé, 2009). The chaos theory has been proved to be an adeguate tool to observe all these seemingly incomprehensible or random systems. Usually natural systems are chaotic.

A league is more competitive when there is more randomness. In fact, this means that the harder it is to predict the final outcome, the tougher the competition will be. Since all teams have a similar performance level, any small change will lead to an imbalance. However, when the competition is less random, the degree of competitiveness will decrease significantly, therefore, we have a competition where there are great opportunities to know the final outcome.

\section{RESEARCH METHODS}

The aim of our study was to analyze the level of competiveness in sport competitions. We studied the results obtained from the North America Professional Basketball League [National Basketball Association] (NBA), 1992/93 to 2008/09 seasons.

Generally, in any official competition, different teams play the same number of games at home and away; showing a confrontation matrix with the same numbers of rows and columns: points scored, wins, losses, points scored and points against. For $N$ teams, there is a matrix of size N x N. See Figure 1 for an example of the matrix $\mathrm{N}=4$.

The vector $\mathrm{R}$ (score vector) represents the results obtained by each team in each season, while the number of games won Ri divided by the number of games played by each team, or ratio (number of wins / number of games played) has the sense of probability.

The result vector $\mathrm{R}$, at first, behaves randomly, in the sense that we do not know the final result,

\begin{tabular}{|c|c|c|c|c|c|c|}
\hline & $\mathbf{a}$ & $\mathbf{b}$ & c & d & HW & $\mathbf{R}$ \\
\hline $\mathbf{a}$ & $x$ & 1 & 0 & 1 & 2 & 4 \\
\hline b & 0 & $x$ & 0 & 0 & 0 & 1 \\
\hline $\mathbf{c}$ & 1 & 1 & $x$ & 1 & 3 & 5 \\
\hline d & 0 & 0 & 1 & $x$ & 1 & 2 \\
\hline $\mathbf{A L}$ & 1 & 2 & 1 & 2 & $x$ & \\
\hline & 2 & 1 & 2 & \multicolumn{2}{|l|}{1} & \\
\hline
\end{tabular}


but the results of the previous seasons (historical performance) may provide some clues. The values of R historical or previous seasons divided by the sum of all games can also be considered as a discrete probability distribution:

$$
p_{i}=\frac{R_{i}}{\sum_{j=1}^{N} R_{j}}
$$

Where $p_{i}$ indicates the probability that the $\mathrm{i}$ team gets a certain result and therefore can be considered as a performance indicator.

In the case of uniform distribution, any team has an equal chance of winning. In terms of statistical mechanics, such distributions are related to equilibrium situations where all structures and gradients have been eliminated. The disorder is maximum therefore; the values of entropy (S) are also maximum.

When the set of probabilities of a system is known, we can define the Shannon entropy (S), which is an average measure of uncertainty and, hence, refers to the average amount of information that contains a random variable. It is defined as:

$$
S=\sum_{i=1}^{N}\left(p_{i} \log 1 / p_{i}\right)
$$

The value of $\mathrm{S}$ changes with the value of $\mathrm{N}$, number of teams, and therefore are not comparable in different seasons if the number of teams changes. Thus, it is preferable to use the normalized entropy (Sn):

$$
S n=\frac{S}{\log (N)}
$$

So the maximum value of $\mathrm{Sn}$ is bounded between 0 and 1 , where 1 corresponds to the situation in which all values are equal to each other.

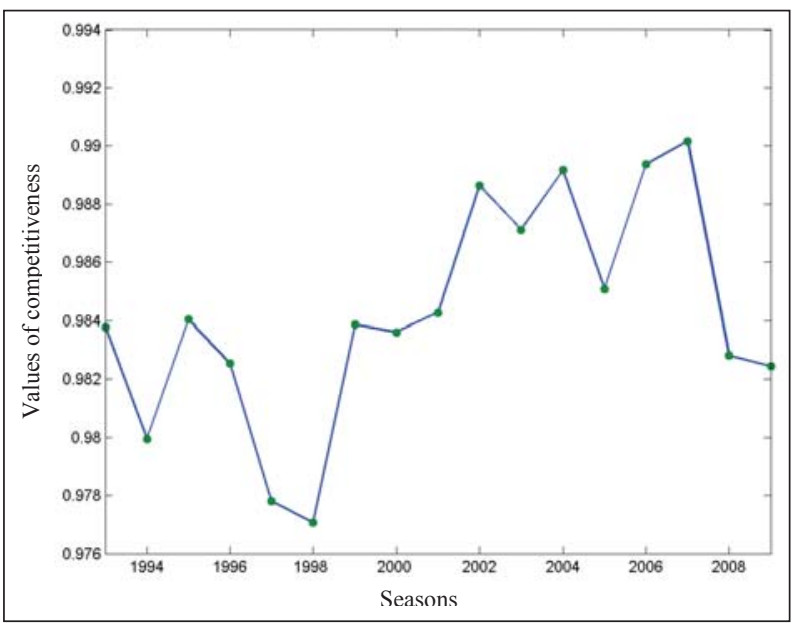

We can express the result table as a set of probabilities, and we can calculate the value of Sn and obtain a parameter that will measure by what extent the system is more or less away from the equilibrium. If we define the equilibrium state as the situation of maximum competitiveness, the Sn value provides a numerical value of competitiveness for a given season. From this point of view, if a competition is less random, the degree of competitiveness is lower, which means that we have a competition with less uncertainty about the final result.

\section{RESEARCH RESULTS}

The NBA has a much more stable entropic tendency. There are seasons less competitive $(\leq 0.9800)$ than the overall average $(0.9835)$, and periods where the competitiveness remains at higher levels (range: 0.9851 to 0.9902 ) (Figure 2). We can clearly see the seasons that do not correspond to this trend, showing a behavior that can be defined as "anomalous" compared to the rest of the trend shown. These seasons are: 1993-1994, 1996-1997, 1997-1998 and the period between 2001-2002 and 2006-2007 seasons.

\section{DISCUSSION}

The NBA is a league of closed structure (no promotions and relegations), which is composed of thirty 30 franchised member clubs, twentynine of which are located in the United States and one in Canada. The current league organization divides thirty teams into two conferences of three divisions with five teams in each. The current divisional alignment was introduced in the 20042005 season. During the regular season, each team plays 82 games, 41 at home and 41 away.

Figure 2. The seventeen NBA seasons analyzed

Note. The $\mathrm{y}$-axis represents the values of entropy (from 0, less competitiveness, to 1, high competitiveness). Entropy of NBA remains stable and close to its average values, showing two diferent periods to this trend. The first one from 1995-1996 season to 19981999 season. The second one from 2000-2001 to 2006-2007. 
A team faces opponents in its own division four times a year (16 games); teams from the other two divisions in its conference either three or four times (36 games); and teams in the other conference twice respectively (30 games). This asymmetrical structure means that the strength of schedule will vary significantly between teams.

The NBA is a franchise-type business model where each team owns rights to their players. In this manner, you can make transfers between franchises, without the player being involved in the operation. Besides, the free agent also exists within limited entrepreneurial skills and regulations.

At the NBA there are economic and player factors that could generate anomalous competitions and unusual results. For example, we observe that during the seasons 1995-1996, 1996-1997 and 1997-1998, Michael Jordan's Chicago Bulls, obtained the best records of wins at the NBA regular season so far (win-lost: 72-10, 69-13 and 62-20 respectively). This monopoly period is probably responsible for the decline in competitiveness at the league, and it is also accompanied by an increased attraction to athletes and the public, as well as private companies and media, resulting in a strong economic impact. It has been estimated that since the arrival of Michael Jordan until his second retirement, the economic impact was about 90000 million Euros (Escudero, 2007).

Another interesting area covers the period 20012002 to 2006-2007 seasons. These correspond with the renegotiation of the salary cap (1999-2005) when the Collective Bargaining Agreement (CBA) was signed. Probably, that fact had an impact on the overall performance of the league, due to the fact that the objective of the salary cap is to prevent teams with large surplus of profits, and it can be signed by the best players available; thereby, facilitating the retention equality in the league. This mechanism, together with the draft, is necessary for each franchise to carefully select which players may be interested in the market for its project (depending on the background of the team). Consequently, each franchise only achieves to "shield" economically one or two players, commonly referred to as "franchise players".

If we consider the team as a complex system, we must bear in mind that one of the defining features of complex systems is the difficult to predict beyond a certain timeframe, and high dependence on initial conditions. But this does not mean that prediction is impossible. The memory of initial conditions is lost within the attractors, as the teams are within the competition, their emerging and chaotic environment. But the attractor itself can be extremely robust. In particular, chaotic does not mean unstable. Chaos means that simple systems can produce complex responses. It is clear that there is nonlinear dynamics alone alive (Amaral et al., 2004).

We must remember that complex systems are usually out of balance. For instance, living organisms are in a constant struggle with their environment to stay in a particular state of equilibrium, i. e. alive (Amaral et al., 2004). In our context, it would mean that to maintain this level of competition so high, it is necessary for a team to be in constant struggle to overcome rivals, and invest huge amounts of energy to survive the competition.

\section{CONCLUSIONS AND PERSPECTIVES}

In conclusion, we can state that the analysis model (Shannon entropy) for the study of the levels of competitiveness in the system of league competition, is a useful and highly sensitive tool to determine the degree of global competitiveness of a league and to detect small oscillations. The potential to detect minimum fluctuations at the level of competition allows us focusing attention on localized temporal changes and investigating the mechanisms which cause them.

\section{REFERENCES}

Amaral, L. A. N., Ottino, J. M. (2004). Complex networks. Augmenting the framework for the study of complex systems. European Physics Journal B, 147-162.

Chatterjee, S., Yilmaz, M. R. (1999). The NBA as an evolving multivariate system. The American Statistician, 53 (3), 257-262.

Escudero, J. (2007). NBA Generation [Generación NBA]. Madrid: JC.

Fort, R., Maxcy, J. (2003). Competitive balance in sports leagues: An introduction. Journal of Sport Economics, 4 (2), 154-160.

Goodwin, B. (2000). How the Leopard Changed its Spots:
The Evolution of Complexity [Las manchas del Leopardo]. Barcelona: Tusqets.

Goossens, K. (2006). Competitive balance in European football: Comparison by adapting measures: National measure of seasonal imbalance and top 3. Rivista di Diritto ed Economia dello Sport, 2 (2), 77-122.

Gréhaigne, J. F., Billard, M., Guillon, R., Roche, J. (1989). Vers une autre conception de l'enseignement des sports collectifs. In G. Bui-Xuan, Méthodologie et Didactique de l'EPS (p.p. 201-216). Clermond-Ferrand: AFRAPS.

Lebed, F. (2006). System approach to games and competitive playing. European Journal of Sport Science, 6, 1, 33-42. 
Malacarne, L. C., Mendes, R. S. (2000). Physica A, 286 (1-2), 391-395.

McGarry, T., Anderson, D. I., Stephen, A. W., Hugues, M. D., Franks, I. M. (2002). Sport competition as a dynamical self-organizing system. Journal of Sports Sciences, 20, $771-781$

McGarry, T., Franks, I. M. (2007). System approach to games and competitive playing: Reply to Lebed (2006). European Journal of Sport Science, 7 (1), 47-53.

Mendes, R. S. Malacarne, L. C., Anteneodo, C. (2007). Statistics of football dynamics. The European Physical Journal B, 57 (3), 357-363.

Onody, R. N., de Castro, P. A. (2004). Complex network study of Brazilian soccer players. Physical Review E, 70, 3.

Passos, P., Araújo, D., Davids, K. W. et al. (2008). Information-governing dynamics of attacker-defender interactions in youth rugby union. Journal of Sports Sciences, 26 (13), 1421-1429.

Passos, P., Araujo, D., Davids, K. W., Milho, J., Gouveia, L. (2009). Power law distributions in pattern dynamics of attackerdefender dyads in the team sport of rugby union: Phenomena in a region of self-organised criticality? E: CO-Emergence: Complexity and Organization, 11 (2), 37-45.

Rhoads, T. A. (2004). Competitive Balance and Conference Realignment in the NCAA: The 74th Annual Meeting of
Southern Economic Association, New Orleans: LA.

Ribeiro, H. V., Mendes, R. S., Malacarne, L. C., Picoli, S., Santoro, P. A. (2010). Dynamics of tournaments: The soccer case. European Physics Journal B, 75 (3), $327-$ 334.

Robert, B. A. (1965). Information Theory. New York: Interscience.

Schmidt, M. B., Berri, D. J. (2001). Competition and attendance: The case of Major League Baseball. Journal of Sports Economics, 2 (2), 145-167.

Shannon, C. E. (1948).A Mathematical theory of communication: Bell system. Technical Journal, 27, 379-423.

Solé, R. (2009). Complex Networks [Redes Complejas]. Barcelona: Tusqets.

Vaz de Melo, P. O. S., Almeida, V. A. F., Loureiro, A. A. F. (2008). Proceeding of the 14th ACM SIGKDD international conference on Knowledge discovery and data mining: International Conference on Knowledge Discovery and Data Mining (pp. 695-703). USA: Las Vegas, Nevada.

Vicsek, T. (2002). Complexity: The bigger picture. Nature, $418,131$.

Yilmaz, M. R., Chatterjee, S. (2000). Patterns of NBA team performance from 1950 to 1998. Journal of Applied Statistics, 27 (5), 555-566.

\title{
NBA REGULIARAUS SEZONO VARŽYMOSI LYGMENS ANALIZE்
}

\author{
Yves de Saá Guerra, Juan Manuel Martín González, Nieves Arjonilla López, \\ Samuel Sarmiento Montesdeoca, David Rodríguez Ruiz, Juan Manuel García Manso \\ Gran Kanarijos las Palmas universitetas, Kanaru salos, Ispanija
}

\section{SANTRAUKA}

Tyrimo pagrindimas ir hipotezė. Skirtingą sporto ekspertų daugiaplanio rungties struktūrinio modelio analizę lemia skirtinga jo samprata. Problema ta, kad dauguma mokslo darbų ši fenomeną studijuoja izoliuotai analizuodami tik paties sportinio žaidimo struktūrą. Tačiau kai kurie tyrejjai ši fenomeną sieja su varžymosi aplinka. Komanda suprantama kaip sudettingas kompleksinis sisteminis vienetas ir jam funkcionuoti būtina sąlyga yra varžybos. Tik varžybos sudaro prielaidą grupei tapti sportine komanda.

Taikytas Shannon entropijos analizès metodas leidžia ne tik nustatyti ir įvertinti komandų bendraji varžymosi lygmeni, bet tiksliai nustatyti ir jo kaitą.

Tikslas: sukurti sportinių žaidimų komandų varžymosi lygmens analizès modelị.

Metodai. Buvo taikyta sporto varžybų - neapibrèžtumo arba atsitiktinumo kriteriju - laisvès laipsnio analizè. Laisvès laipsnis buvo skaičiuojamas pagal Shannon metodą.

Rezultatai. Taikant ši modeli tirta 17 reguliarių NBA sezonų. Pastebèta gana stabili entropijos tendencija. Pasitaikè mažesnio varžymosi $(\leq 0,9800)$, lyginant su vidurkiu $(0,9835)$, ir didelio varžymosi (nuo 0,9851 iki 0,9902) lygmens sezonų.

Aptarimas ir išvados. Didesnis varžymosi lygmens atsitiktinumų laisvès laipsnis lemia NBA lygos komandu varžymosi laisvès laipsni. Atskirų rungtynių baigties rezultatai neprognozuojami. Kita vertus, mažèjant varžymosi lygmens laisvès laipsniui, mažėja rungtynių baigties lygmens laisvès laipsnis, taip pat reikšmingai sumažeja konkurencingumas.

Galima daryti išvadą, kad NBA yra labai konkurencinga lyga. Rungtynių baigties neapibrèžtumo laisvès laipsnis gana didelis.

Raktažodžiai: kompleksinės sistemos, krepšinis, entropija, varžybos, atsitiktinumas.

Gauta 2010 m. rugsèjo 13 d.

Received on September 13, 2010

Priimta $2011 \mathrm{~m}$. kovo $17 \mathrm{~d}$.

Accepted on March 17, 2011
Corresponding author Yves de Saá Guerra University of Las Palmas de Gran Canaria Building of Educacion Fisica

35017 Canary Island

Spain

Tel +34928454406

E-mail yvesdesaa@gmail.com 